\title{
The development of gonad mantis shrimp Harpiosquilla raphidea Fabricius, 1798 in Banten Bay, Indonesia
}

\author{
Mugi Mulyono1*, Mufti Petala Patria², Abinawanto², Ridwan Affandi ${ }^{3}$ and Mardiyono
}

1) Jakarta Fisheries University, Jakarta, 12520, Indonesia.

2) Departement of Biology, Faculty of Mathematics and Natural Science, Universitas Indonesia, Depok, 16424, Indonesia.

3) Department of Aquatic Resources Management, Faculty of Fisheries and Marine Sciences, Bogor Agricultural University, Kampus FPIKIPB, Darmaga, Bogor 16680, Indonesia.

Received: July-29-2016

Accepted: October-03-2016

Published: January-01-2017

\begin{abstract}
The Harpiosquilla raphidea mantis shrimp in Banten Bay is very important and an abundant marine crustacean in Indonesia. It is common among the most important predators in many shallow, tropical and subtropical marine habitats. Gonad maturity level of mantis shrimp Harpiosquilla raphidea was identified in four phases of development. The first size mature gonad of the female mantis shrimp is 199 $\mathrm{mm}$ and the male is $230 \mathrm{~mm}$. The gonad maturity level of the female shrimp in II, III and IV have fecundity ranging from 24.600 to 76.809 , with an average of $54.082 \pm 13.456$ where as the diameter of the eggs at gonad maturity level III is $510-675 \mu \mathrm{m}$, with an average diameter of $574 \pm 6.98 \mu \mathrm{m}$.
\end{abstract}

Keywords: Banten Bay, Mantis shrimp, Harpiosquilla raphidea, gonad maturity, Indonesia

\section{Introduction}

The Harpiosquilla raphidea mantis shrimp is an order Stomatopoda shrimp living in subtidal areas between 2-43 m with mud substrate or sandy mud (Moosa, 1975). The population of the $H$. raphidea mantis shrimp is found in several waters in the North Java Sea, such as in Banten Way Waters.

The study of the shrimp's reproduction requires a knowledge of the gonad's development on the individual shrimp. The method normally used is based on the morphological structure. The visual method may be faster but proved to be less accurate. The histological method can be used to obtain detailed analysis concerning the development of oosit and spermatosit (Wortham-Neal, 2002; Kodama et al., 2006).

Based on the importance of population biological data for the conservation of the mantis shrimp $(H$. raphidea) in Banten Bay waters, a reproductive aspects is needed. In general, study of the reproductive aspects of mantis shrimp ( $H$. raphidea) has very rarely been reported. Indonesia, especially in Banten Bay waters, study of the reproductive biology of the mantis shrimp has not been conducted. The result of this study is expected to be benefitin formulating the first steps in the management of the mantis shrimp ( $H$. raphidea) to be sustainable, both ecologically and economically, particularly in Banten Bay waters, and in Indonesia waters in general.

\section{Material and Method Location of Study}

The study was conducted from December 2011 to February 2012 with the sample location of mantis shrimp's population in Banten Bay waters in the Province of Banten. The analysis of the reproductive biology of the structure of gonads histology and morphology was conducted in the Fish Health Laboratory, Sekolah Tinggi Perikanan Jakarta (Jakarta Fisheries University) Fisheries Health, Jakarta Fish Quarantine Agency.

\section{Material of Study}

The sample of mantis shrimps used as material for the reproductive biological study from Banten Bay waters from December 2011 to December 2012. The sample mantis shrimps were measured by length and weight, determination of sex was determined using the Wortham-Neal (2002) method. The tools used were bottom gillnet pulled by motorboat, GPS, multi checker for water quality, plastic bags, mica plastic, 
rubber bracelet, cool box, digital balance, ruler and digital camera. The tools used for making the histological network were dissecting set, tissue processor, microtome, microscope and water bath.

On the female mantis shrimp, we measured egg diameter and number of eggs. We used female mantis shrimp sample on gonad maturating level III. The egg sample taken was from the anterior, centre and posterior part. Determination of spawning type can be made by the dissemination graphic of the mantis shrimp's egg diameter with the mature gonad. The gonad histology was performed following Muladno (2006) and Wibowo (2011).

First size prediction of the mature gonad was based on Sperman-Karber method (King, 1995). The criterion for a mature gonad maturating level III, and the formula used was:

$\log M=X_{k}+\frac{\bar{x}}{2}-\left(\bar{x} \sum P i\right)$

$X_{k}=$ Medium score of logarithm at the time when gonad is $100 \%$ ripe

$\bar{X}=$ The average difference between the logarithm of the mean value

$\mathrm{Pi}=\mathrm{ri} / \mathrm{ni}$

$\mathrm{ri}=$ Number of mature gonad shrimp on first class

$\mathrm{ni}=$ Total number of shrimps

The type of reproduction was determined based on the distribution of egg diameter according to its distribution modus.

\section{Result}

Sex Ratio

Mantis shrimp caught during the study numbered 332 , consisting of 146 males and 186 females depends on difference of behaviour and the fishing factor. A Chi square test was conducted to support the result.

\section{The Development of Gonad}

The histological and morphological structure of the gonad was used to identify the level of gonad maturity of males and females. The morphological observation was based on colour, size and gonad volume, while the histological observation was based on histological structure. The development of the gonad is in four phases: gonad maturity level I (immature), gonad maturity level II (premature), gonad maturity level III (mature) and gonad maturity level IV (post-mature) following Vila et al., (2013) and Wortham-Neal (2002).

The morphological structure of the level 1 mantis shrimp resembles a thin thread extended along the back of the carapace to the rear of the abdomen, and is tinted translucent or transparent. The larger level II male gonads were seen clearly between the border intestinal organ, had a broken white colour (RAL 1013) and the length of gonad was not extended up to the telson (Table. 1). Level III gonads were bigger, almost filling the inner abdomen, and had creamy white colour (RAL 1015). Level IV was post-spawning, smaller than level III and were light brown in colour (RAL 1000).

Tab. 1: Assessment criteria of gonad maturity of male mantis shrimp by histology and morphology.

\begin{tabular}{|c|c|c|}
\hline Gonad Maturating Level & Morphology & Histology \\
\hline $\begin{array}{c}\text { I } \\
\text { (early development) }\end{array}$ & $\begin{array}{l}\text { Testicle shaped like thread, around the } \\
\text { intestinal and testicular tinted light or } \\
\text { transparent with RAL Signal white standard, } \\
9003 \text { Fig. } 1(1 \mathrm{a}) \text {. } \\
\text { Testicular strands are increasingly visible in } \\
\text { the digestive organs and increasingly white } \\
\text { colour with RAL Oyster white } 1013 \\
\text { standard, filling } 1 / 8 \text { abdominal cavity or } \\
\text { stomach. Fig. } 1(1 \mathrm{~b}) \text {. }\end{array}$ & $\begin{array}{l}\text { Testicle has developed and the } \\
\text { connective tissue is already visible, } \\
\text { tubulus sack has been filled by } \\
\text { Spermatosit. } \\
\text { Testicular is dominated by secondary } \\
\text { spermatosoit and developed as } \\
\text { spermatid. }\end{array}$ \\
\hline $\begin{array}{c}\text { III } \\
\text { (mature) }\end{array}$ & $\begin{array}{l}\text { Testicle fills } 1 / 4 \text { abdominal cavity or stomach, } \\
\text { testicle has creams colour with RAL Light } \\
\text { ivory } 1015 \text { standard, shaped like branches } \\
\text { and the dissemination extends to the telson } \\
\text { part. Fig. } 2 \text { (1c). }\end{array}$ & $\begin{array}{l}\text { Developed Spermatid becomes } \\
\text { spermatozoa clearly seen filling the } \\
\text { seminifer tubulus. }\end{array}$ \\
\hline $\begin{array}{c}\text { IV } \\
\text { (post-mature) }\end{array}$ & $\begin{array}{l}\text { Testicle is wrinkled, pale cream colour with } \\
\text { RAL Green beige } 1000 \text { standard } \\
\text { Filling } 1 / 5 \text { abdominal cavity or stomach. Fig. } \\
2 \text { (1d). }\end{array}$ & $\begin{array}{l}\text { On post-maturity, it was seen that the } \\
\text { rest of spermatozoa has not been } \\
\text { taken out. }\end{array}$ \\
\hline
\end{tabular}


The morphological structure of the female ovary was like a thin thread extending along the back of the carapace to the rear of the abdomen, tinted translucent or transparent. The level II ovary was bigger and clear on the border of intestinal organ; having a light yellow colour (RAL 1018) and not fully extended to the telson (Fig. 1). The level III gonad was bigger, almost filling the inner abdomen, having ark yellow colour (RAL 1003). Level IV was smaller than level III, with yellow orange colour (RAL 4002) or light orange (Table. 2).

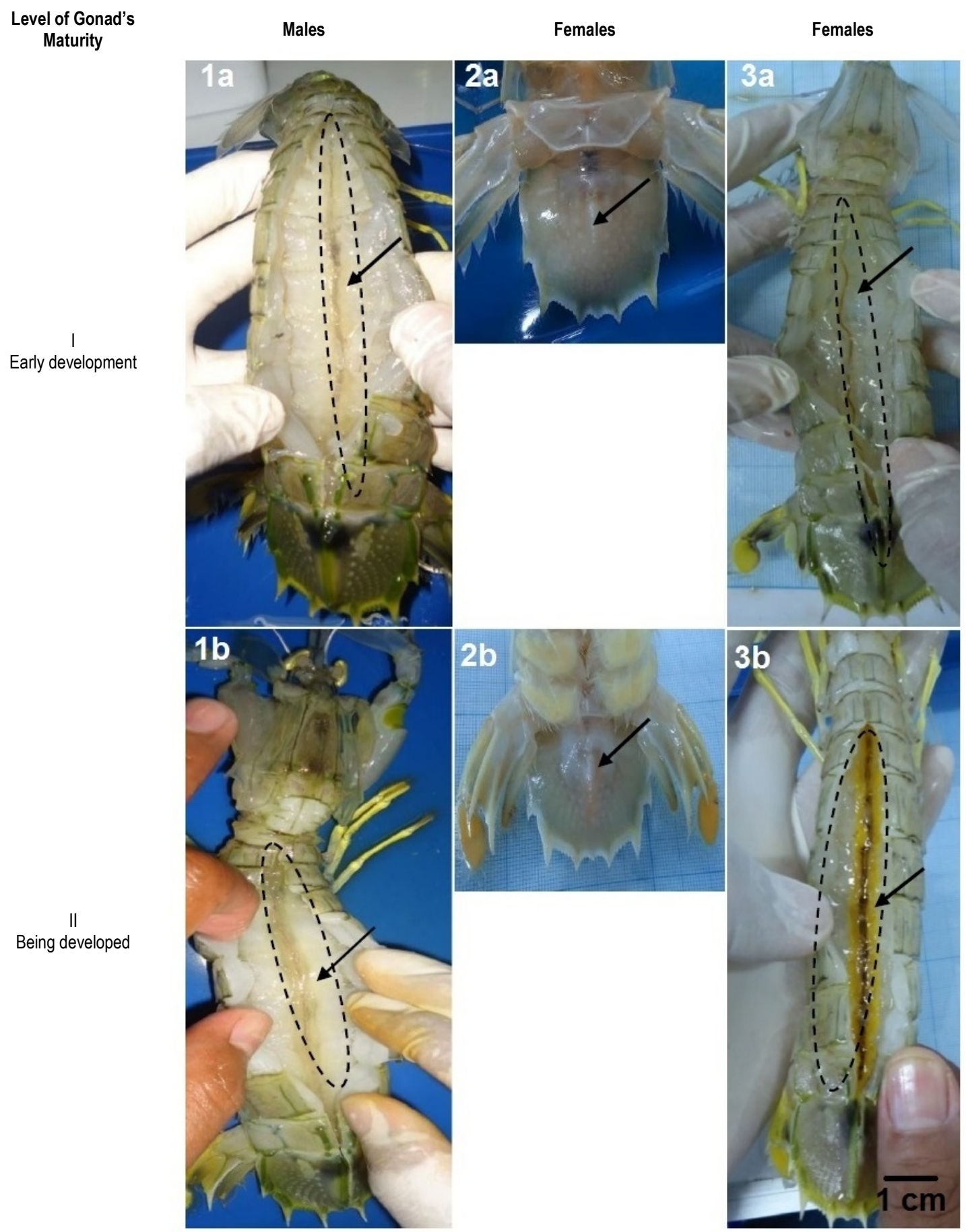

Fig. 1: Gonad's morphological structure and the male and female mantis shrimp at gonad maturating level land level II. The arrow signs show the position of the gonad.1a: gonad maturating level I male on dorsal, $1 \mathrm{~b}$ : Male of gonad maturating level II on dorsal, 2a: Female gonad maturating level I at telson part, 2b:Female gonad maturating level II on telson, 3a: Female gonad maturating level I on dorsal part, 3b: females on gonad maturating level II on dorsalpart. 
Tab. 2: Assessment criteria on gonad maturity of female mantis shrimp by histology and morphology.

\begin{tabular}{|c|c|c|}
\hline Gonad Maturating Level & Morphology & Histology \\
\hline $\begin{array}{c}\text { I } \\
\text { (early development) }\end{array}$ & $\begin{array}{l}\text { The ovarium is transparent and light cream and between } \\
\text { the digestive organs, but the egg is not visible yet. } \\
\text { Figure.1. ( } 3 a \text { ). } \\
\text { On exoskeleton lower part telson the white freckles are } \\
\text { seen with RAL Grey white } 9002 \text { standard, and not the } \\
\text { yellow colour is not seen. Fig. } 1(2 a) \text {. }\end{array}$ & $\begin{array}{l}\text { Cytoplasma is seen to have a clear, } \\
\text { purple colour. The cell nucleus is } \\
\text { clearly visible. }\end{array}$ \\
\hline $\begin{array}{c}\| \\
\text { (being developed) }\end{array}$ & $\begin{array}{l}\text { Yellow colour with RAL Zinc yellow } 1018 \text { standard, has } \\
\text { thick form and has fills } 1 / 3 \text { of the abdominal cavity and } \\
\text { visible from the back end of carapace to the front end of } \\
\text { telson. Figure.1. (3b). On the lower part of telson the } \\
\text { yellow colour of egg starts to be visible and has been filling } \\
\text { the telson. Fig. } 1(2 \mathrm{~b}) \text {. }\end{array}$ & $\begin{array}{l}\text { Ovarium is dominated with } \\
\text { secondary oosit that has been } \\
\text { developing to become ootid. The oosit } \\
\text { diameter is around } 300-450 \mu \mathrm{m} \text { and } \\
\text { the egg yolk is visible on sitoplasma } \\
\text { with reddish colour. }\end{array}$ \\
\hline $\begin{array}{c}\text { III } \\
\text { (mature) }\end{array}$ & $\begin{array}{l}\text { Ovarium has orange colour with RAL Signal yellow } 1003 \\
\text { standard, the form of the egg is visible and fills } 2 / 3 \text { of the } \\
\text { abdominal cavity or stomach to the inner part of telson. } \\
\text { Figure.1.(3c). The lower part of telson has a yellow colour } \\
\text { nd clearly shows the egg has filled the telson Fig. } 2(2 \mathrm{c}) \text {. }\end{array}$ & $\begin{array}{l}\text { At this phase, the egg yolk is visible, } \\
\text { and the ovarium also shows the } \\
\text { nucleus with the oosit diameter } \\
\text { around } 478-655 \mu \mathrm{m} \text {. }\end{array}$ \\
\hline $\begin{array}{c}\text { IV } \\
\text { (post-mature) }\end{array}$ & $\begin{array}{l}\text { Ovarium fills } 1 / 4 \text { of abdominal cavity, the orange colour is } \\
\text { visible and becomes red with RAL Sand yellow } 4002 \\
\text { standard, the remains of egg seen rarely. } \\
\text { On the lower part of the telson is seen the yellow colour } \\
\text { from the egg's remains, and the volume is smaller than } \\
\text { gonad maturating level III Fig. } 2 \text { (2d). }\end{array}$ & $\begin{array}{l}\text { Oosit is around } 450-600 \mu \mathrm{m} \text {. On this } \\
\text { phase, oosit looks wrinkled with } \\
\text { different sizes and the ovarium is } \\
\text { also irregular. }\end{array}$ \\
\hline
\end{tabular}

Morphological characteristics are more pronounced in females than males. The colour and the volume of the lower part of the telson changed as the gonad developed. In level I the lower part of the telson was transparent; however, yellow colouring began to develop in level II from the upper part to the lower part. In level III the yellow colour was more intense than level II and spread out more widely inside the telson. In level IV the yellow colour started to fade compared to level III (Fig. 2).

The results of the analysis based on the histology of gonadal development indicates a change of development and size spermatosid or oosit of gonadal development Level I to IV. Histological structures were described in details in (Fig. 3).

\section{Spawning period}

The change in colour of the gonad indicated the peak of spawning period between March to April and September to October.

\section{Discusion}

The sex ratio of the mantis shrimp showed that the balance of female and male shrimp can change based on place and time. Sallam (2005) reported the result of study on mantis shrimp Erugosquilla massavensis with a sex ratio: 1:1. Studies on Gonodactylids demonstrated an increase in male mortality rate due to fighting each time they breed (Caldwell, 1986). The number of males was lower than females during shrimp breeding season in other stomatopoda species (Hamano and Matsuura 1987; Froglia and Giannini, 1989; Dittel, 1991; Wortham-Neal, 2002), $E$. Massavensis (Sallam, 2000; El-Ganainy et al., 2004) having a balanced sex ratio. Sex ratio determines the sustainability of species, since the number of female and male mantis shrimp can be influenced by the predator level or fighting among male shrimps (Mashar, 2010).

The level of gonad maturity can be used as the probe status of shrimp's reproduction, age and first size of mature gonad, proportion of stock that are productively mature for understanding the reproductive cycle for one population or species. The level of gonad growth in female shrimp consists of four phases based on gonad's morphological and histological characteristics. There is a close relation between gonad maturity and gonad maturity index. To determine the level of gonad maturity, it is divided into four phases of growth: beginning, starting to mature, mature and post-mature. El-Syarif et al., (2012), on the other hand, classified the level of gonad maturity in six phases, classified in ten phases of gonad growth of the mantis shrimp Oratosquilla oratoria in Tokyo Bay. Gonad growth and maturity level reaches a maximum limit when the spawning is about to begin. In this case, the change of gonad maturity level value was close to gonad growth phase. The decrease in maturity size of first gonad of female mantis shrimp $E$. massavensis in Egyptian waters had been attributed 


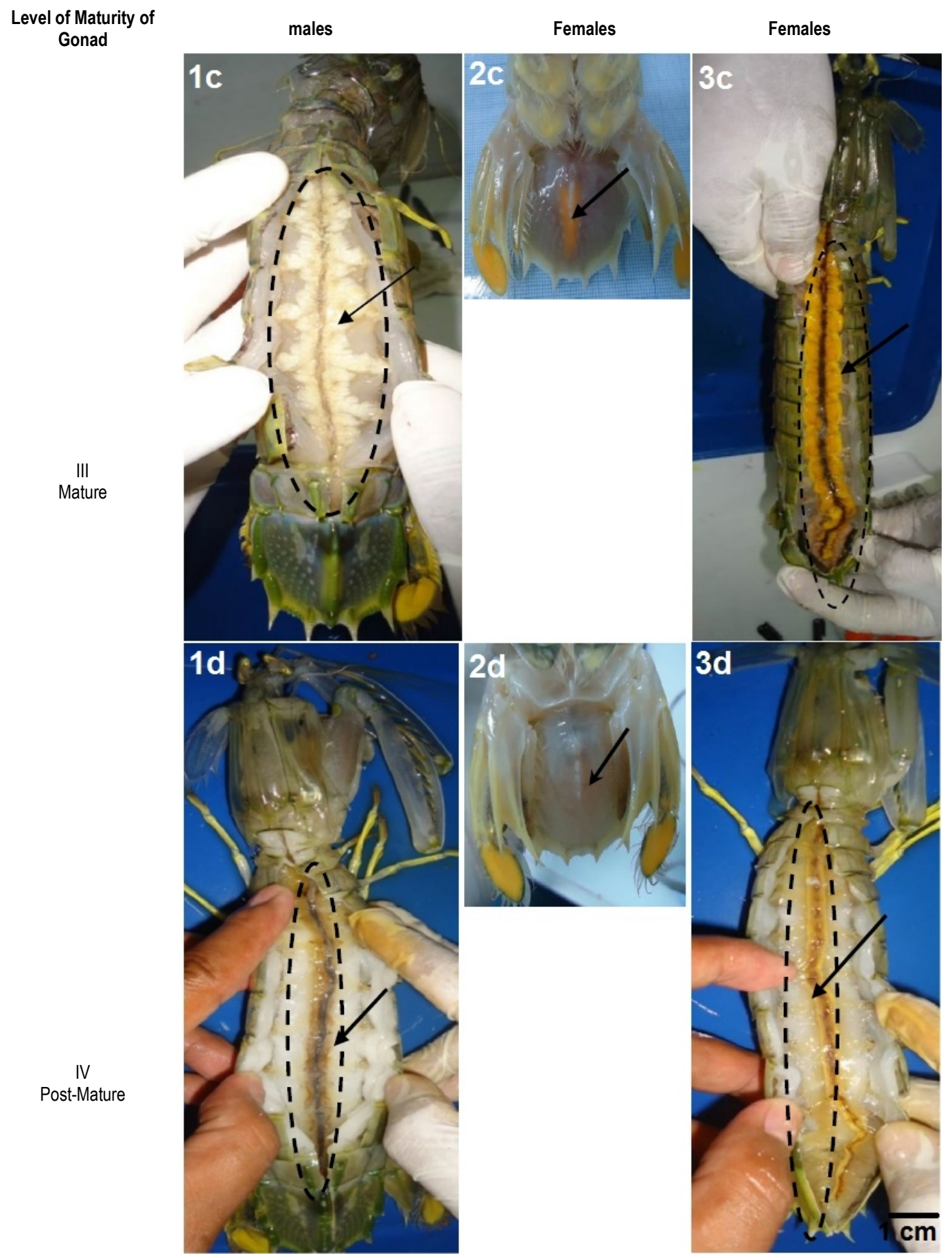

Fig. 2: Gonad's morphological structure of mantis shrimp male and female on gonad maturating level III and level IV. The arrow signs show the gonads on dorsal and the pictures show us the position of the gonad.1c: gonad maturating level III females on dorsal.1d : Male gonad maturating level IV on dorsal part, 2c: Female gonad maturating level III on telson part, 2d: Female gonad maturating level IV on telson part, 3c: Female gonad maturating levellll dorsal part, 3d: Female gonad maturating level IV on dorsal part. 


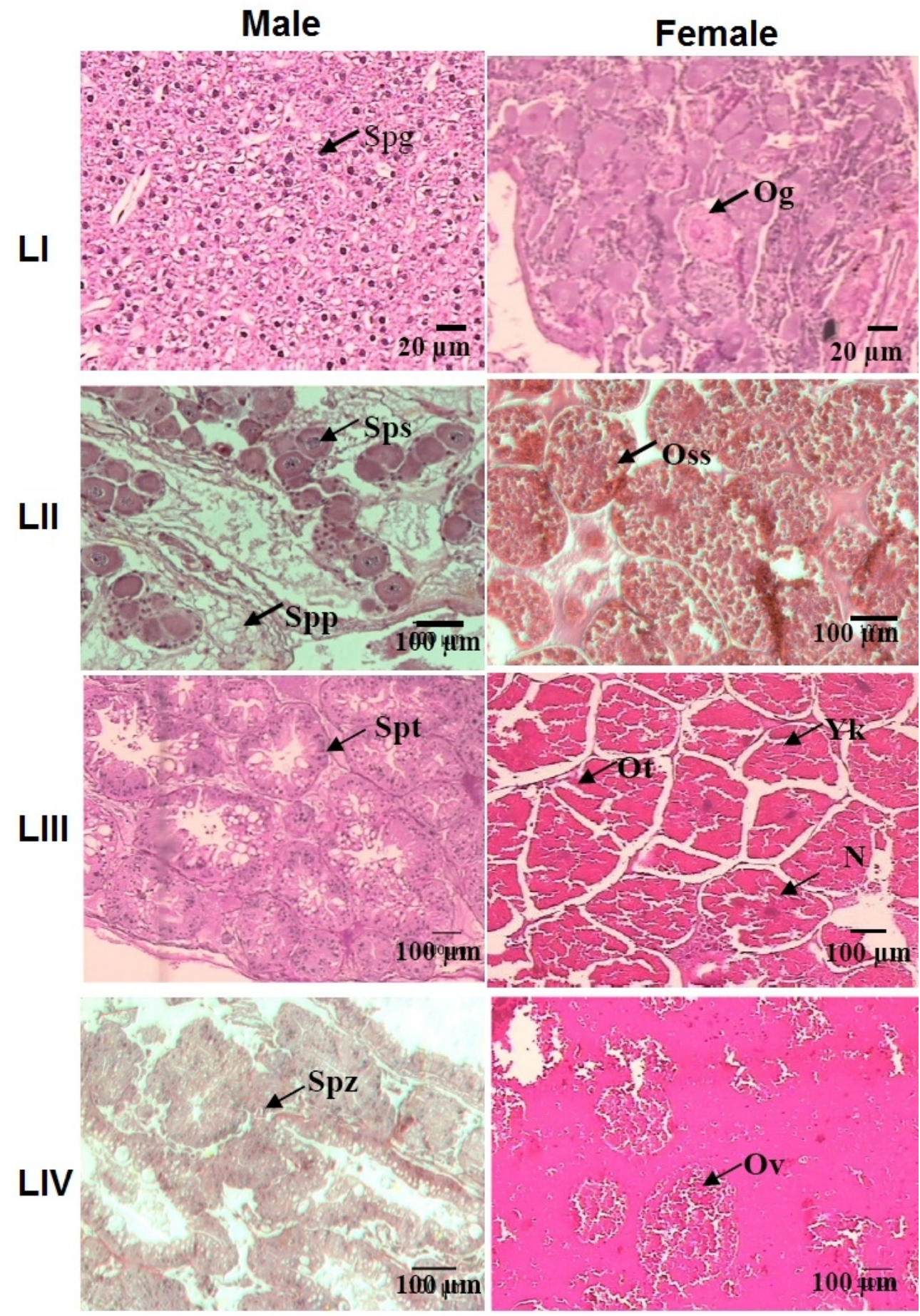

Fig. 3: The view of gonad histological structure of female and male mantis shrimp. Spg = spermagonium, Spp = spermatosit primer, Sps secondary spermatosit, $\mathrm{Spt}=$ spermatid, $\mathrm{Spz}=$ spermatozoa, $\mathrm{Og}=$ oogonium, $\mathrm{Osp}=$ oosit primer, Oss $=$ secondary oosit, $\mathrm{Ot}=$ otid $\mathrm{Ov}=$ ovum, $\mathrm{N}=$ cell and $\mathrm{Yk}=$ yolk

by Sallam (2000) and Sallam (2005) to overexploitation. The overfishing activity of the mantis shrimp Oratosquillaoratoria in Tokyo Bay (Ohtomi and Shimizu, 1991) also contributed to the change in size in gonads.

Fluctuation and the change of environment conditions had influenced the gonad maturation process. It was observed that for mantis shrimp larvae, the gonad's maturation process had a close relationship with the waters environment signals, such as the provision of food (van der Wall, 2006).

Variations in the first size of maturity was observed in the gonads for female and male mantis shrimp (Harpiosquilla raphidea). The size of first male mature gonad had a total length (TL) of $230 \mathrm{~mm}$ or carapace length $(\mathrm{CL})$ of $51.52 \mathrm{~mm}$, while female mantis shrimp 
had a TL of $199 \mathrm{~mm}$ or CL of $44.58 \mathrm{~mm}$.

It was observed for the Squilla mantis shrimp in Caciz Bay that it had the first maturity of gonad at $\mathrm{CL}$ around $23.7 \mathrm{~mm}$ (Vila et al., 2013), while Abello and Martin (1993) in Delta Erbo, Spain had found the first size mature gonad of the male Squilla mantis shrimp around $15.2 \mathrm{~cm}$ and the female around $14.5 \mathrm{~cm}$. On the other hand, Abello and Sarda (1989) reported the TL to be around $11.13 \mathrm{~cm}$. According to Nikolsky (1963), the first size of mature gonad was probably influenced by the abundance and provision of food, temperature, lighting period and the environmental factor of water habitats or different waters. Several factors that caused the difference of the first size of mature gonad were due to population genetics, differences in rates of growth and the quality of waters (Paugy 2002); the differences of area and the fishing pressure also influenced the first size of mature gonad (Reynolds et al., 2001).

Type of spawning is related to the development and egg diameter could be used to identify the pattern of shrimp spawning. The fecundity ofthe mantis shrimp (Harpiosquilla raphidea)was found to be different from the fecundity for female E. massavensis (Sallam, 2000). The fecundity of $H$. raphidea was greater than other species of mantis shrimp Harpioquilla (Giovanardi and Piccinetti, 1983; Hamano et al., 1987. Fecundity was reported to be negatively correlated to water environment pressure and over-exploitation (Reaka, 1979; Sallam, 2000).

The dissemination pattern of shrimp egg diameter showed that mantis shrimp could be classified as being a total spawner. The research result of Kodama et al. (2006) on the mantis shrimp Oratosquila oratoria showed a similar dissemination pattern with the oncespawning type even though the spawning season and time were different. In controlled conditions, the mantis shrimp Oratosquilla oratoria showed a dissemination pattern that did not vary, but all the eggs were released during 3 days (Hamano and Matsuura, 1984). The difference of egg diameter could be determined according to the level of egg maturity, while the difference of fecundity was determined by the gonad maturity index.

\section{Conclusion}

The sex ratio between male and female mantis shrimp Harpiosquilla raphidea is in balance. The first size of mature gonad of the male mantis shrimp $H$. raphidea is larger than the female. The spawning peak season of mantis shrimp $H$. raphidea in Banten Bay waters is observed to be in March-April and SeptemberOctober $H$. raphidea is a total spawner.

\section{References}

$\checkmark$ Abello P. and Martin P. (1993) Fishery dynamics of the mantis shrimp Squilla mantis (Crustacea: Stomatopoda) population off the Ebro Delta. Fisheries Research, 16: 169-175.

$\checkmark$ Ahyong S.T. (2001) Revision of the Australian Stomatopoda Crustacea. Records of the Australian Museum. Suplement, 26.

$\checkmark$ Ahyong S.T., Chan T.Y and Liao Y.C. (2008) A catalog of the mantis shrimp (Stomatopoda) of Taiwan. National Taiwan Ocean University. Keelung.

$\checkmark$ Ahyong S.T and Moosa M.K. (2004) Stomatopod crustacea from Anambas and Natuna Island, South China Sea, Indonesia. The Raffles Bulletin of Zoology, 11: 6166.

$\checkmark$ Ahyong S.T and Edrmann M.V. (2007) Two species of Gonodactylellus from the Western Pasifik (Gonodactylidea: Stomatopoda). The Raffles Bulletin of Zoology, National University of Singapore, 55(1): 89-95.

$\checkmark$ Al-Sherif S., El-Khodary G.M. and Ghonim A.Z. (2012) Ovarian cycle and scanning electron micrographs of the spawned egg of female mantis shrimp Oratosquilla massevensis (Alexandria, Egypt). Journal of Basic and Applied Biology, 6: 2090-2096.

$\checkmark$ Chambers S.M and Bayless J.W. (1983) Cummings Publishing Company Inc. New York.

$\checkmark$ Effendie, M.I. (1997) Biological Fisheries Method. Pusaka Nusatama. Yogyakarta.

$\checkmark$ Caldwell, R.L. (1991) Variation in reproductive behavoiur in stomatopod Crustacea. In, Crustacean sexual biology. Bauer R.T. and Martin J.W. (eds). Columbia University Press. New York: 67 - 90.

$\checkmark$ Dittel A.L (1991) Distribution, abundance and sexual composition of Stomatopods in the Gulf of Nicoya, Costa Rica. Journal of Crustacea. Biology, 20: 269 - 276.

$\checkmark$ El-Ganainy, A.A., Sallam. W.S. and Yassin, M. (2004) Population Dynamics of the Mantis Shrimp Erugosquilla massavensis (Crustacea: Stomatopoda) from the Eastern Mediterranean Sea, Egypt. Proc. I.C.B.S., 3 (1): 88-100.

$\checkmark$ Froglia. C. and Giannini S. (1989) Field observations on diel rhythms incatehability and feeding of Squilla mantis (L.) Crustacea Stomatopoda in the Adriatic Sea. In. Ferrero E.A (ed.). Biology of Stomatopods. Muccho. Modena: 221-228.

$\checkmark$ Hamano T. and Matsura S. (1984) Egg laying and egg mass nursing behaviour in the Japanese mantis shrimp. Bulletin of the Japanese Society of Scientific Fisheries, 50: 1969-1973.

$\checkmark$ Hamano T., Morrissy N.M. and Matsura S. (1987) Ecological information on Oratosquilla oratoria (Stomatopoda, Crustacea) with an attempt to estimate the annual settlement date from growth parameters. Journal of Shimonoseki University of Fisheries, 36: 9-27.

$\checkmark$ Kodama K., Shimizu T., Yamakawa T. and Aoki I. (2004) Reproductive biology of the female Japanese mantis 
shrimp Oratosquilla oratoria (Stomatopoda) in relation to changes in the seasonal pattern of larval occurrence in Tokyo Bay, Japan. Fisheries Science, 70: 734-745.

$\checkmark$ Kodama K., Yamakawa T., Shimizu T. and Aoki I. (2005) Age estimation of the wild population of Japanese mantis shrimp Oratosquilla oratoria (Crustacea: Stomatopoda) in Tokyo Bay, Japan, using lipofuscin as an age marker. Fisheries Science, 71: 141-150.

$\checkmark$ Kodama K., Shimizu T., Yamakawa T. and Aoki I. (2006) Changes in reproductive patterns in relation to decline in stock abundance of the Japanese mantis shrimp Oratosquilla oratoriain Tokyo Bay. Fisheries Science, 72: 568-577.

$\checkmark$ Kubo I., Hori S., Kumemura M., Naganawa M. and Soedjono J. (1959) A biological study on a Japanese edible mantis-shrimp, Squilla oratoria De Haan. Journal of the Tokyo University of Fisheries, 45: 1-25.

$\checkmark$ Manning R.B. (1969) A review of the genus Harpiosquilla (Crustacea: Stomatopoda) with description of three new species. Smithsonian Contribution of zoology. Smithsonian Institution Press. City of Washington.

$\checkmark$ Manning R.B. (1995) Stomatopoda crustacea of Vietnam: the legacy of Raoul Serene. Crustacea research, 4: 1-339.

$\checkmark$ Mayunar. (2002) Observations some aspects morphometric and reproductive biology ronggeng shrimp, Harpiosquilla harpax (De Haan). National Seminar Crustasea 2nd. Bogor, 122-129.

$\checkmark$ Moosa M.K. (1975) Note on Stomatopoda Crustacea from Seribu Islands and adjacent water with the discription of a new spesies. Marine Reaseach in Indonesian, 15: 1-20.

$\checkmark$ Moosa M.K. (1982) Faughnia serenei, new species, a stomatopod from the South China Sea (Crustacea, Stomatopoda). Journal Crustacea Biology, 2(4): 600 -604. $\checkmark$ Moosa M.K. (1989) Some Stomatopoda (Crustacea: Stomatopoda) from Japanese waters, with the discription of a new spesies. Bulletin of the National Science Museum Tokyo, series A (Zoology), 15(4): 223-229.

$\checkmark$ Moosa M.K. (2000) Marine biodiversity of South China Sea: A checklist of Stomatopoda Crustacea. The Raffles Bulletin of Zoology, 8: 405-457.

$\checkmark$ Nikolsky G.V. (1963) The ecology of fishes. Academic Press. New York.

$\checkmark$ Ohtomi J. and Shimizu M. (1994) Teoritical growth during the recruitment period and estimation of growth parameters of the Japanese mantis shrimp Oratosquilla oratoria in Tokyo Bay. Bulletin of the Japanese Society of Fisheries and Oceanography, 58(1): 21-27.

$\checkmark$ Pauly D. (1989) A selection of simple methods for the assesment of tropical fish stock. Manual FAO, Fish Circulation., FIEI/C701: 325.

$\checkmark$ Reaka M.L. (1979) The evolutionary ecology of life history patterns in stomatopod Crustacea. In. Stancyk S. (ed.,) Reproductive ecology of marine invertebrates, 235-260.

$\checkmark$ Sallam W.S. (2000) Studies on the biology of mantis shrimps in the Suez Canal. Ph.D. thesis. Suez Canal University. Egypt.

$\checkmark$ Walpole R.E. (1995) Statistical of Introduction. PT. Gramedia Pustaka Utama. Jakarta.

$\checkmark$ Wardiatno Y. and Mashar A. (2010) Biological information on the mantis shrimp, Harpiosquilla raphidea (Fabricius 1798) (Stomatopoda: Crustacea) in Indonesia with a highlight of its reproductive aspects. Journal of Tropical and Conservation, 7:63-73.

$\checkmark$ Wortham-Neal J.L. (2002) Reproductive morphology and biology of male and female mantis shrimp (Stomatopoda: Squillidae). Journalof Crustacean Biology, 22(4): 728-748. 